UDC: $616.24-007.272-036.12$

\title{
TO THE PROBLEM OF COMORBIDITY AND SYNTHROPY IN CHRONIC OBSTRUCTIVE PULMONARY DISEASE
}

\author{
Ospanova T. S., Semidotskaya Zh. D., Chernyakova I. O., Avdeyeva O. V., Pionova O. M., \\ Tryfonova N. S. \\ Kharkiv National Medical University, Kharkiv, Ukraine
}

The study objective is to establish the relationships features between lipid profile and other parameters of homeostasis in case of chronic obstructive pulmonary disease in framework comorbidity with coronary artery disease and arterial hypertension.

Materials and methods: the lipid profile, CRP, IgE, $\mathrm{HbA}_{1} \mathrm{C}, \mathrm{FEV}_{1}$, Tiffno's index and $\mathrm{SpO}_{2}$ in 35 patients with chronic obstructive pulmonary disease (groups B, C, D), that were studied by standard methods.

Results: A large quantity of correlations between different indicators that increased in relation to disease progression and presence of comorbidity was found. Cluster analysis confirmed the affinity between these indicators.

Conclusion: A large quantity of correlation links between lipids and other indices of homeostasis and the results of cluster analysis indicate the development of adaptation and disadaptation processes under such circumstances as elevation of hypoxia in chronic obstructive pulmonary disease and these might be evaluated as synthropy of comorbidity with coronary artery disease and arterial hypertension.

KEY WORDS: chronic obstructive pulmonary disease, lipid profile, comorbidity, synthropy

\section{ЩОДО ПРОБЛЕМИ КОМОРБІДНОСТІ ТА СИНТРОПІЇ ПРИ ХРОНІЧНОМУ ОБСТРУКТИВНОМУ ЗАХВОРЮВАННІ ЛЕГЕНЬ}

\author{
Оспанова Т. С., Семидоцька Ж. Д., Чернякова І. О., Авдєєва О. В., Піонова О. М., \\ Трифонова Н. С. \\ Харківський національний медичний університет, м. Харків, Україна
}

Мета роботи - встановити особливості взаємодії ліпідного спектру 3 іншими показниками гомеостазу при коморбідності хронічного обструктивного захворювання легень із ішемічною хворобою серця та гіпертонічною хворобою.

Матеріали й методи: у 35 пацієнтів із хронічним обструктивним захворюванням легень (групи В, C, D) досліджені показники ліпідного спектру, рівні СРБ, IgE, $\mathrm{HbA}_{1} \mathrm{C}, \mathrm{OФB} \mathrm{1,} \mathrm{індекс} \mathrm{Тифно} \mathrm{та} \mathrm{SpO}_{2}$ стандартними методами.

Результати: Виявлено велику кількість кореляційних зв'язків між різними показниками, кількість яких зростає при прогресуванні хвороби та коморбідності. Кластерний аналіз підтвердив наявність спорідненості між цими показниками.

Заключення. Велика кількість кореляційних зв'язків між ліпідами та іншими показниками гомеостазу, результати кластерного аналізу свідчать про розвиток процесів адаптації та дезадаптації в умовах наростаючої гіпоксії при хронічному обструктивному захворюванні легень і можуть бути оцінені як синтропія при коморбідності з ішемічною хворобою серця та гіпертонічною хворобою.

КЛЮЧОВІ СЛОВА: хронічне обструктивне захворювання легень, ліпідний профіль, коморбідність, синтропія

\section{К ПРОБЛЕМЕ КОМОРБИДНОСТИ И СИНТРОПИИ ПРИ ХРОНИЧЕСКОМ ОБСТРУКТИВНОМ ЗАБОЛЕВАНИИ ЛЕГКИХ}

Оспанова Т. С., Семидоцкая Ж. Д., Чернякова И. А., Авдеева Е. В., Пионова Е. Н., Трифонова Н. С.

Харьковский национальный медицинский университет, г. Харьков, Украина

(C) Ospanova T. S., Semidotskaya Zh. D.,

Chernyakova I. O., Avdeyeva O. V., Pionova O. M.

Tryfonova N. S., 2018 
Цель работы - установить особенности взаимодействий липидного спектра с другими показателями гомеостаза при коморбидности хронического обструктивного заболевания легких с ишемической болезнью сердца и гипертонической болезнью.

Материалы и методы: у 35 пациентов с хроническим обструктивным заболеванием легких (группы В, C, D) исследованы показатели липидного спектра, уровни СРБ, IgE, HbA, C, ОФВ 1, индекс Тиффно, $\mathrm{SpO}_{2}$ стандартными методами.

Результаты: Обнаружено большое количество корреляционных связей между различными показателями, нарастающее по мере прогрессирования болезни и при коморбидности. Кластерный анализ подтвердил наличие сродства между этими показателями.

Заключение. Большое количество корреляционных связей между липидами и другими показателями гомеостаза, результаты кластерного анализа свидетельствуют о развитии процессов адаптации и дезадаптации в условиях нарастающей гипоксии при ХОЗЛ и могут оцениваться как синтропия при коморбидности с ишемической болезнью сердца и гипертонической болезнью.

КЛЮЧЕВЫЕ СЛОВА: хроническая обструктивная болезнь легких, липидный профиль, коморбидность, синтропия

"When we are examining an adult patient,
we rarely meet with one pathological form;
generally, the presented pathological facts
have different origin in time and reason.»

S. Botkin

\section{INTRODUCTION}

Interest into the problem of comorbidity and synthropy in various diseases is increasing nowadays [1-7]. This interest is explained by new data in the interrelations of a genome and a phenome which evolve depending on environmental conditions. The concept of «diseasome» is introduced, which means the whole complex of inherited diseases, including their genes and the ability to express these genes. It is a complex network of links between diseases and genes that determine them, the integration of all genetic disorders (disease phenome) and the network of disease genes (disease genome) [8]. Syntrophic genes, which are responsible for the development of comorbid diseases, are identified. Neutral genetic markers that determine the predisposition to diseases are also identified. Studies are existed to prove the presence of specific adverse alleles of genes that determine the development of cardiorespiratory pathology in chronic obstructive pulmonary disease (COPD), occupational lung diseases, and bronchial asthma [9].

The achievements of molecular biology, genomics and molecular genetics have deepened our understanding about human diseases, taking into consideration all factors contributing to the development of the disease, from a network approach to genome, phenome and diseasome associations. At the same time genes take various functional positions in the network of interaction [10]. Comorbid states were an incentive for studying general mecha- nisms of pathogenesis of various diseases [6]. The numerous connections between lifestyle and environmental influences on physiological, clinical, molecular, and genetic levels were discovered in large-scale cohort studies. They have provided a new under-standing of health, premorbid and multimorbid conditions.

Synthropy reflects the tendency of living organisms functioning to achieve higher levels of vital activity organization in new conditions and creates a special phenotype of the disease. It supposes the necessity of a holistic, personified approach to the prevention, diagnosis, treatment and prognosis of the disease, studying of universal network interactions at the genomic, molecular, cellular levels. From the synthropy position this approach can ensure the development of «networked» pharmacotherapy taking into account emergence, constantly arising new pathogenetic properties and connections at certain phases in the disease evolution [11].

\section{OBJECTIVE}

Study of relationships features between lipid profile and other parameters of homeostasis at COPD in framework comorbidity with coronary artery disease $(\mathrm{CAD})$, arterial hypertension $(\mathrm{AH})$ and type 2 diabetes mellitus (DM).

\section{MATERIALS AND METHODS}

Integrative principles were used to design study: 32 parameters of homeostasis were studied, $9^{\text {th }}$ of which were studied in the 
treatment process (oxygen saturation $\left(\mathrm{SpO}_{2}\right)$, forced expiratory volume in 1 second $\left(\mathrm{FEV}_{1}\right)$, forced vital capacity (FVC), Tiffno's index $\left(\mathrm{FEV}_{1} / \mathrm{FVC}\right.$ ratio), reversibility test of airways obstruction with bronchodilator agent, results of CAT and mMDR questionnaires).

35 COPD patients $(57.14 \%$ male and $42.68 \%$ female) aged from 42 to 82 years, the average age was 57.0 [54.0-67.0] suffering from COPD exacerbation and comorbid pathology were examined according to standard protocols. The average COPD duration was $10.02[5.0-15.0]$ years.

All patients underwent clinical examination, assessment of complete blood count, clinical urine test, and sputum analysis, carbohydrate metabolism and determine level of creatinine, $\mathrm{IgE}$, and $\mathrm{C}$ - reactive protein (CRP).

Fasting concentration of total cholesterol (TC), triglycerides (TG), high density lipoproteins (HDL), low density lipoproteins (LDL) and very low density lipoproteins (VLDL) were carried out via standard biochemical methods. Climov's formula was used to count atherogenic index (AI). The level of total $\mathrm{IgE}$ was determined with chemiluminescent immunoassay method. Determination of the serum concentration of CRP was performed by immunoturbidimetric method. Glomerular filtration rate (GFR) was evaluated via Cockcroft-Gault formula.

The pulmonary function test (PFT) was performed by using a computer spirograph («Spirocom», Scientific and Technical Center of Radioelectronic Devices and Technologies, Kharkov, UA). Bronchodilator reversibility was measured in a half an hour after inhalation of salbutamol $0.4 \mathrm{mg}$.

The statistical analysis was carried out by using nonparametric methods of the package Statistica 10. The data are represented by the median $(\mathrm{Me})$ with interquartile range $(\mathrm{Me}$ [25\%-75\%]), unless otherwise indicated. The relationship between the variables was estimated with Spearman's rank-order correlation $(p<0.05)$. Cluster analysis with complete linkage was performed.

\section{RESULTS AND DISCUSSION}

According to design of our study the parameter of lipid profile (TC, TG, HDL, LDL,
VLDL, and AI) and their correlation with other studied parameters are presented in the article.

The comorbidity was noted in $23 \mathrm{COPD}$ patients, 11 COPD patients type 2 DM was diagnosed, 8 COPD patients had CAD (cardiosclerosis, stable angina), and 4 COPD patients had AH II stage.

According to the classification proposed by GOLD 2014, patients were divided into 3 groups: group B-12 patients, group C-14 patients, group D-9 patients. The prevalence of the comorbid diseases in each group were: in group B $8.33 \%$ of patients did not have accompanying pathology, $16.6 \%$ had $\mathrm{AH}$, $16.6 \%$ had CAD, $58.33 \%$ had AH combined with CAD (in 3 - postinfarction cardiosclerosis). In group C $21.43 \%$ of patients did not have accompanying diseases, $\mathrm{CAD}$ were found in $28.7 \%$ of patients and $50 \%$ of patients had $\mathrm{AH}$ associated with $\mathrm{CAD}$. Comorbid pathology was found in all patients group D: $22.22 \%$ had CAD and $77.78 \%$ had AH combined with CAD.

A comparative analysis of the lipid profile (Table) indicates a tendency for an increase in LDL and $\mathrm{AI}$ at comorbidity with CAD (in comparison with the group without $\mathrm{CAD}$ ). These differences are especially pronounced for TC and TG $(\mathrm{p}<0.05)$.

The lowering of VLDL in the group with CAD mismatches from the overall trend. A tendency towards increase TC, TG, VLDL, LDL and decrease in HDL was determined in COPD patients with hypertension as well.

It should be borne in mind while interpreting the shifts of the lipid spectrum that TGs are an important energy substrate, cholesterol is a component of cell membranes and intracellular organelles. These lipids are water insoluble and transferred in the composition of lipoproteins, complexes of lipids with specific proteins (apolipoproteins). VLDL transport endogenous TG from the liver to other tissues, LDL provide cholesterol transport from the liver to peripheral tissues, HDL are associated with reverse transport from peripheral tissues to the liver, from where it can be eliminated. Thus all lipoproteins are in a dynamic state and between them there is an intensive exchange of lipids and proteins. 
Table

Comparative characteristic of lipid profile depends on presence of comorbid pathology

\begin{tabular}{|c|c|c|c|c|c|}
\hline & COPD & $\begin{array}{c}\text { COPD with } \\
\text { CAD }\end{array}$ & $\begin{array}{c}\text { COPD without } \\
\text { CAD }\end{array}$ & COPD with AH & $\begin{array}{c}\text { COPD without } \\
\text { AH }\end{array}$ \\
\hline TC, mmol/l & $\begin{array}{c}6.20 \\
{[4.80-6.45]}\end{array}$ & $\begin{array}{c}6.20 \\
{[5.3-6.5]}\end{array}$ & $\begin{array}{c}5.70^{*} \\
{[4.80-6.40]}\end{array}$ & $\begin{array}{c}6.34 \\
{[4.80-6.34]}\end{array}$ & $\begin{array}{c}6.13 \\
{[5.45-6.78]}\end{array}$ \\
\hline $\mathrm{HDL}$, & 1.21 & 1.30 & 1.14 & 1.23 & 1.30 \\
$\mathrm{mmol} / \mathrm{l}$ & {$[1.12-1.37]$} & {$[1.15-1.37]$} & {$[1.12-1.18]$} & {$[1.12-1.37]$} & {$[1.15-1.40]$} \\
\hline $\mathrm{TG}, \mathrm{mmol} / 1$ & 2.76 & 2.78 & $1.69^{*}$ & 2.80 & 2.12 \\
& {$[1.47-3.22]$} & {$[1.46-3.24]$} & {$[1.55-2.70]$} & {$[1.46-3.24]$} & {$[1.53-2.99]$} \\
\hline $\mathrm{LDL}$, & 3.70 & 3.96 & 3.45 & 4.20 & 3.96 \\
$\mathrm{mmol} / \mathrm{l}$ & {$[3.0-4.22]$} & {$[3.20-4.22]$} & {$[2.44-3.68]$} & {$[2.44-4.22]$} & {$[3.21-4.39]$} \\
\hline $\mathrm{VLDL}$, & 0.85 & 0.82 & 0.94 & 1.10 & 0.94 \\
$\mathrm{mmol} / 1$ & {$[0.48-1.13]$} & {$[0.53-1.13]$} & {$[0.48-1.10]$} & {$[0.53-1.10]$} & {$[0.30-1.45]$} \\
\hline $\mathrm{AI}$ & 3.47 & 3.55 & 3.55 & 3.55 & 3.35 \\
& {$[2.86-4.50]$} & {$[3.03-4.50]$} & {$[2.55-4.43]$} & {$[2.60-4.50]$} & {$[3.04-4.58]$} \\
\hline
\end{tabular}

Note: * - significant difference between the indices in the COPD group with CAD and without CAD $(p<0.05)$.

V. J. Marshall [12] recommends distinguishing «ideal» and «abnormal» lipid levels in serum. The levels of TC and TG in all groups of examined patients were elevated in comparison with the «ideal» ones, TG level was «abnormally» high (more than $2.5 \mathrm{mmol} / \mathrm{l}$ ) either in whole group of COPD patients or at comorbidity with AH or CHD $(3.2 \mathrm{mmol} / \mathrm{l}$, $2.8 \mathrm{mmol} / 1,3.2 \mathrm{mmol} / \mathrm{l}$, respectively).

Significant changes in the number of correlations between different indices of homeostasis were found depending on the clinical group of COPD: the number of significant correlations was 94 in group B, in group $\mathrm{C}-134$, in group $\mathrm{D}-112(\mathrm{p}<0.05)$. This may be associated with an intensification of the adaptation processes to the disease in group $\mathrm{C}$ and the subsequent depletion of compensatory mechanisms in group D. Similar trends were observed at comorbidity with CAD (in the group of CAD the number of correlations was 156 , in the group without $\mathrm{CAD}$ - 71) and at comorbidity of $\mathrm{AH}$ (in the group with $\mathrm{AH}$ the number of correlations was 159 , without $\mathrm{AH}-109)$.

The analysis of statistically significant interrelationship with the lipid profile in the whole group of COPD patients revealed a moderate uphill relationship between TC and CRP $(\mathrm{R}=0.55)$ indicating the lipids participation in the development of systemic inflammation. 14 correlations with parameters of lipid profile were found among overall COPD patients, while in groups B and C -13 , in group $\mathrm{D}-15$.
Correlations between HDL and body mass index (BMI) $(\mathrm{R}=0.69)$ as well as waist circumference $(R=0.58)$ in group $B$ and inverse moderate relationship between level of reversibility of airflow obstruction and HDL $(\mathrm{R}=-0.62)$ and IA $(\mathrm{R}=-0.62)$ were found.

There is a strong positive correlation of CRP with $\mathrm{TC}(\mathrm{R}=0.80)$ and $\mathrm{LDL}(\mathrm{R}=0.95)$ in group $\mathrm{C}$, which indicates an increase lipid involvement in the systemic inflammatory process in COPD. Besides there are positive correlations between $\mathrm{TC}, \mathrm{TG}$ and $\mathrm{SpO}_{2}$ $(\mathrm{R}=0.57$ and $\mathrm{R}=0.64$, respectively). Additionally, positive moderate relationship between TG and Tiffno's index $(\mathrm{R}=0.56)$, TC and GFR $(\mathrm{R}=0.62)$ was noted.

Positive moderate correlation between HDL and $\mathrm{SpO}_{2} \quad(\mathrm{R}=0.68)$, strong relationship between $\mathrm{TG}$ and $\operatorname{IgE}(\mathrm{R}=0.72)$, and negative strong correlation between TC and FVC $(\mathrm{R}=$ $-0.70)$ were noted in group $\mathrm{D}$. The peculiarity of this group is a large number of correlations which might be considered paradoxical. Positive correlations of TC (high) and CA (moderate) with Tiffno's index $(\mathrm{R}=0.89$ and $\mathrm{R}=0.67$, respectively), positive correlations of LDL (high) and VLDL (moderate) with GFR ( $R=0.81$ and $R=0.67$, respectively) belong to them.

Analysis of correlation in COPD patients without comorbidity with $\mathrm{CAD}$ revealed high positive correlations of $\mathrm{HDL}$ with $\mathrm{SpO}_{2}$ $(\mathrm{R}=0.94)$ and reversibility of bronchial obstruction $(\mathrm{R}=0.92)$. 
The quantity of significant correlation relations increases with CAD comorbidity: relationship appears between TC and CRP $(\mathrm{R}=0.498)$ which indicates the participation of lipids in systemic inflammation, and positive correlation between TC and Tiffno's index $(\mathrm{R}=0.39)$ also appears.

6 significant correlations of various parameters with lipids were found in the COPD patients without CAD: positive relationship between $\mathrm{TC}$ and CRP $(\mathrm{R}=0.75), \quad$ GFR $(\mathrm{R}=0.698)$, $\operatorname{IgE} \quad(\mathrm{R}=0.61)$. There was a positive correlation of $\mathrm{HDL}$ with $\mathrm{HbA}_{1} \mathrm{C}$ $(\mathrm{R}=0.76)$. There was a positive strong relationship between LDL and GFR $(\mathrm{R}=0.88)$, and moderate negative between VLDL and $\mathrm{SpO}_{2}(\mathrm{R}=-0.65)$.

The total number of correlations is retained at the comorbidity of COPD and AH. The relationship disappears between TC and CRP, IgE, besides relationship appears between HDL and waist circumference $(\mathrm{R}=0.42)$, VLDL and $\mathrm{HbA}_{1} \mathrm{C}(\mathrm{R}=0.499)$, HDL and GFR $(\mathrm{R}=0.57)$, TC and the Tiffno's index $(\mathrm{R}=0.42)$.

Consequently, lipids form a large quantity of correlations with various parameters of homeostasis at COPD such as CRP, Tiffno's index, reversibility of bronchial obstruction, $\mathrm{SpO}_{2}, \mathrm{IgE}, \mathrm{HbA}_{1} \mathrm{C} .75$ correlation links with lipids were identified totally: there were identified 14 relations throughout group of COPD patients, 13 - in group B, 13 - in group $\mathrm{C}, 15$ - in group $\mathrm{D}, 8-$ in group of COPD with comorbidities of CAD, 4 - without CAD, 9 - in presence of $\mathrm{AH}$ as well as without AH. It should be noticed that the greatest number of interrelations were found with TC, LDL, VLDL and AI as a whole in COPD patients, only the link was detected with TG and no correlations with HDL. Comorbidity with $\mathrm{CAD}$ in COPD patients leads to an increase number of correlations in 2 times, which is not observed at worsening of COPD and comorbidity with AH. Namely, 5 relationships with TC, 4 correlations with pro-atherogenic lipoproteins, no relationship with HDL were found at comorbidity of COPD with CAD. Atherogenic fractions of lipids form 7 relationships with AH comorbidity, association with TC (3 links), LDL and VLDL (2 links), TG (2 links) and HDL (2 links) are presented in COPD patients without $\mathrm{AH}$.

It should be noted that the variety and liability of correlation links, opposite direction, presence of relations, which are difficult to explain, and at glance, taking into account modern conception about the role and functions of lipids, these correlations seem to be paradoxical. Such correlations include a positive moderate association of TC with $\mathrm{LDL}$ $(\mathrm{R}=0.41)$ and GFR $(\mathrm{R}=0.40)$, a negative association between TC and waist circumference $(\mathrm{R}=-0.36)$ in overall COPD patients; out of 15 correlations 3 and might be considered as unexpected.

In addition, 3 out of 14 association revealed in group B are paradoxical, as follows, negative relationship between HDL and reversibility of bronchial obstruction $(\mathrm{R}=-0.62)$, positive association of HDL with BMI $(\mathrm{R}=0.69)$ and waist circumference $(\mathrm{R}=0.58)$.

Furthermore, 4 of the 13 correlations revealed in group $\mathrm{C}$ are paradoxical, so it is a positive correlation with GFR $(\mathrm{R}=0.62)$, positive association of TC with TG $(\mathrm{R}=0.57)$ and $\mathrm{SpO}_{2}(\mathrm{R}=0.64)$, TG and Tiffno's index $(\mathrm{R}=0.56)$.

Moreover, the greatest quantity of paradoxical links ( 6 out of 15 , twice as many as in the other groups) was identified: between TC and the Tiffno's index estimated before and after treatment $(\mathrm{R}=0.73$ and $\mathrm{R}=0.89$, respectively), between TC and $\mathrm{FEV}_{1}$ after treatment $(\mathrm{R}=0.73)$, between $\mathrm{LDL}$ and GFR $(\mathrm{R}=0.66)$, AI and Tiffno's index $(\mathrm{R}=0.67)$. In addition, the correlation of $\mathrm{TG}$ with $\mathrm{IgE}$ $(\mathrm{R}=0.72)$ appears precisely in this group. The level of TC was associated with $\operatorname{IgE}(\mathrm{R}=0.61)$ at comorbidity with $\mathrm{AH}$ and as well as correlation between $\mathrm{HbA}_{1} \mathrm{C}$ and VLDL $(\mathrm{R}=0.499)$.

Since the pathogenesis of comorbid states is currently considered in terms of systemic biology and general pathology as a change in universal network processes occurring at the genomic, molecular, and cellular levels we provide data about of correlations quantity in different subgroups of patients. Analyzing correlation relationships it is necessary to identify the most important and significant things in the informational flow and to look for parameters of order in it. A large number of paired associations can arise indirectly through other associations of concomitant diseases, and their number may increase exponentially with an increase in comorbidity [6]. Mistakes in evaluating the results of the study can also be associated with incorrect coding of diseases, inaccuracies in the collection of information, the effects of therapy, and, paradoxically, the 
genetic factors themselves. Mathematical solutions are used in the network science to reduce the impact of indirect relationships between indicators; however, probabilistic relationships between diseases are not taken into account the complex system.

Metabolic networks, formed by groups of interacting proteins, carbohydrates, lipids, etc., are functioning together, coordinate and control the interrelated processes in the body. Networks are represented as a set of «nodes, hub», related oriented (enzyme - substrate, gene - protein, etc.) and undirected «ribs». There are distinguished the central nodes that have a greater number of connections, and peripheral, the number of connections which is much smaller.

The change in the activity of the central nodes contributes development of comorbid pathology. Complex biological systems acquire new (emergent) properties that cannot be explained due to particular diseases. Perhaps, these key positions in system biology and medicine may show the development of synthropies [3] and can explain the «paradox» correlations that were found in patients with COPD.

It is thought that synthropy is either a desire of living organisms to order the functioning of systems, organs, tissues, cells and to reduce entropy processes or a destruction, chaos, movement toward death. From this statement, the appearance of a large number of correlations, including paradoxical ones, in the group $\mathrm{D}$ with the $100 \%$ comorbidity might be considered as manifestation of the synthropy. It is possible to regard such connections of the pulmonary function (PF) indicators with lipids as manifestations of adaptation in case of progressive hypoxia, hypoxemia, and hypercapnia through involvement in the maintenance of homeostasis of lipids, which stabilize cell membranes and are a source of energy.

New mathematical approaches arise in response to the emergence of «unsolvable tasks» in other fields of science and practice. These unsolvable tasks constitute the «noknowledge card» that every scientist has and which is a priority for his research and linked to practical activities, the ability to manage processes.

Paradox correlations between different indicators (lipids, IgE and $\mathrm{HbA}_{1} \mathrm{C}$ ) are related to this «no-knowledge card» in our study. They also probably reflect the unknown processes of the organism adaptation to the organism's struggle with the severe, incurable disease through the involvement of lipids in this process.

The role of lipids in adaptive reactions is associated with the state of cell membranes structures under the pathology conditions that occurs when a system of protective, compensatory and restorative mechanisms is disrupted. Membrane adaptation is associated with changes in the composition of lipids and the functioning of transport systems.

Membrane adaptation is the basis of the ability to maintain adequate metabolic functions of organs and tissues. An important role is played by peroxidation syndrome of cell membranes [13] triggered by peroxisome proliferator-activated receptor (PPAR). PPAR relates to the central nodes of the metabolic network and causes the formation of a large number of connections with different homeostatic systems. The lipid matrix is considered as the most mobile structure of the metabolic network. The change in the phase state of the lipid matrix of biomembranes is determined their stability by damaging factors which go beyond the ranges of self-regulation, a pathological process develops. This determines the lipid strategy of biochemical adaptation to extreme effects; in particular, it is smoking and impact of other damaging environmental factors in case of COPD [14]. Possible clinical manifestations of such adaptation may be changes in the lipid spectrum, atherosclerosis, $\mathrm{AH}$, gastrointestinal lesions, etc. Synthropic genes regulate phenotypes of clinical manifesttations in the case of synthropy.

Our study confirmed the involvement of lipids in systemic inflammation: correlations of TC with CRP in the group of patients with COPD $(\mathrm{R}=0.52)$, group $\mathrm{C}(\mathrm{R}=0.80)$, in case of comorbidity with CAD ( $R=0.498)$, in the group without $\mathrm{AH}(\mathrm{R}=0.75)$ were found.

It is possible to explain the results obtained by the impact of hypoxia on local and systemic inflammation, which increase systemic oxidative stress since PF in all patients declined. Active forms of oxygen start up processes of lipids and lipoproteins oxidation, accumulation of cholesterol, and enhance the systemic inflammatory response, the symptoms of which are presence of acute phase proteins, and especially CRP.

Unexpected correlations between lipids and $\operatorname{IgE}$ were found such as between $\mathrm{TG}$ and $\mathrm{IgE}$ $(\mathrm{R}=0.76)$ in the $\mathrm{D}$ group and between TC and $\operatorname{IgE}(\mathrm{R}=0.61)$ in the group without $\mathrm{AH}$. 
Development of immediate type hypersensitivity reactions in patients with COPD is known and it is associated with sensitizing effects of tobacco smoke and environmental factors [15-16]. Pro-atherogenic properties of $\mathrm{IgE}$ are demonstrated in some studies [17-21]. The increase level of $\operatorname{IgE}$ in patients with unstable angina, dyslipidemia is established. It emphasizes the association of IgE with lipids and the instability of atherosclerotic plaque. Lipids correlate with the genes of basophils and mast cells; IgE accumulates in plaques and contributes to their increase. The opinion is expressed [21] that mast cells play a key role in the development of atherosclerosis and mastocytes secrete pro-atherogenic lipids in plaques.

These processes may not be accompanied with systemic manifestations, the total IgE level does not correlate with atherosclerosis progression. IgE functions in plaques causing accumulation of lipids, degradation of the matrix of the vascular wall and infiltration with pro-inflammatory immune cells. It is considered as key mechanisms of atherosclerosis development and pathogenesis of the plaque rupture.
The relationships between $\mathrm{HDL}$ and $\mathrm{HbA}_{1} \mathrm{C}$ $(\mathrm{R}=0.76)$ in the group of patients without $\mathrm{AH}$ and VLDL with $\mathrm{HbA}_{1} \mathrm{C}(\mathrm{R}=0.499)$ in the group with $\mathrm{AH}$ were found. It confirms the relationship between lipid and carbohydrate metabolism in COPD patients. Among our patients 11 of them had type $2 \mathrm{DM}$, it is possible that synthropy of COPD with this disease not only $\mathrm{CAD}$ and $\mathrm{AH}$ might be present. The comorbidity of COPD and type 2 DM leads to severe COPD, frequent exacerbations, progressive reduction of ventilatory lung function as well as patient's life quality deterioration [22-25].

Cluster analysis of 12 indices (Fig. 1) including of lipid metabolism indices, CRP, anthropometric parameters (BMI), PFT indices $\left(\mathrm{FEV}_{1}\right.$, Tiffno's index) showed that $\mathrm{HbA}_{1} \mathrm{C}$ forms a subcluster with TC. It also enters a cluster that includes a lipid spectrum, CRP and BMI on a large distance. Thus, $\mathrm{HbA}_{1} \mathrm{C}$ is related closely to lipid metabolism, CRP and Tiffno's index forming COPD phenotype with metabolic syndrome (MS). $\mathrm{FEV}_{1}$ and $\mathrm{IgE}$ form a separate cluster, so IgE might be the one of the markers of the eosinophilic phenotype of COPD.

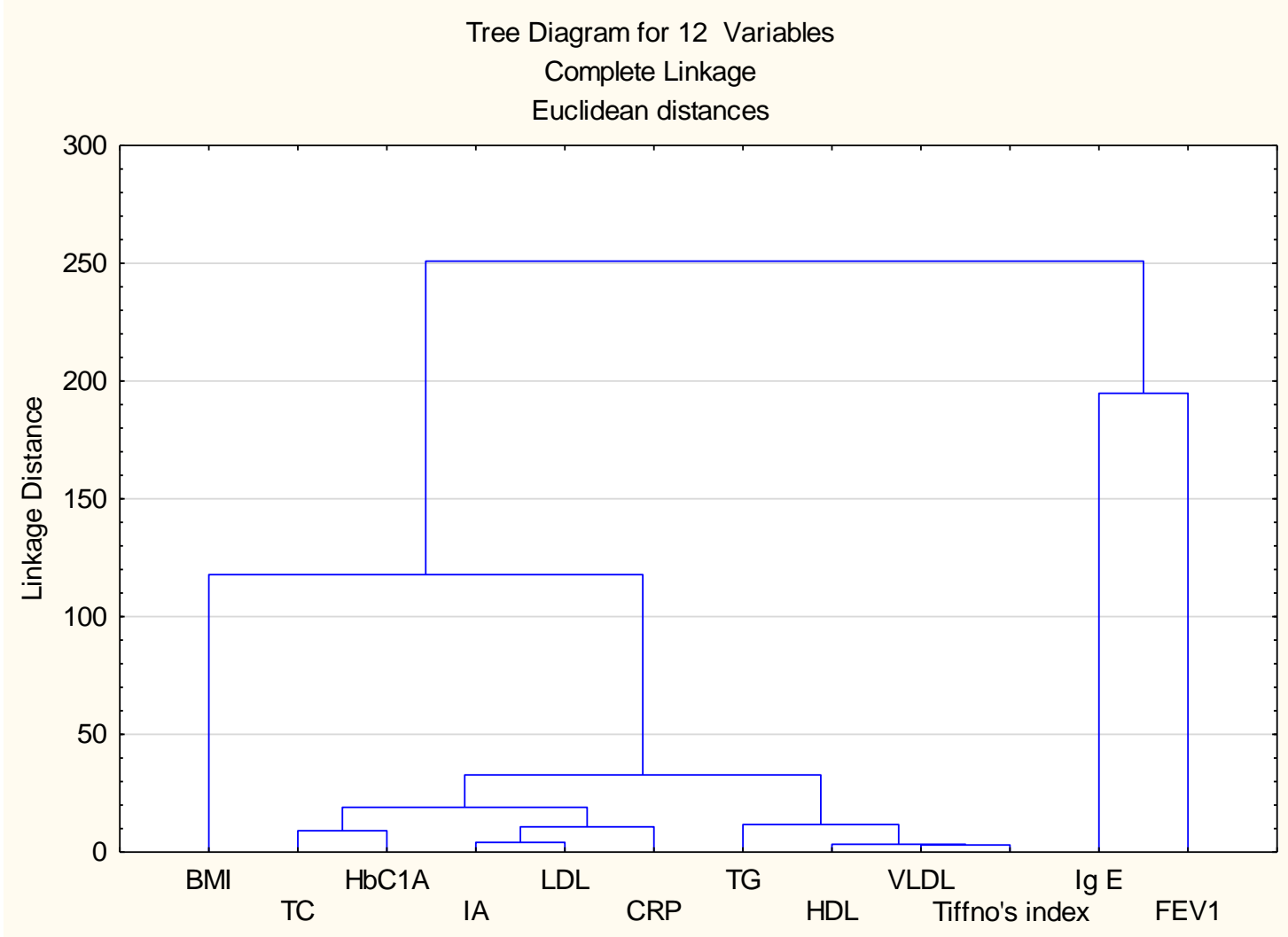

Fig. 1. Cluster analysis of lipid profile, systemic inflammation, pulmonary function and anthropometric data in patients with COPD with comorbid pathology 
Investigation's results [25-29] of COPD comorbidity with MS are published. The opinion is suggested that MS (obesity, hypertension, atherogenic dyslipidemia, hyperglycemia, and insulin resistance) is predisposing factor in the development of systemic inflammation. Abdominal-visceral adipose tissue is considered as an active endocrine organ that supports a chronic systemic inflammatory process. Hypoxia due to COPD disrupts the balance between proinflammatory and anti-inflammatory factors in the large adipocytes zone, and activates the signaling pathways of inflammatory reactions [30]. Patients with MS and COPD have higher CRP and IL-6 levels, than patients without MS. The concentration of adiponectin inversely correlates with BMI in case of obesity. Adiponectin reduces insulin resistance by activating insulin in hepatocytes. Reduced level of adiponectin increases inflammation in the lung tissue. The severity of metabolic obesity should be assessed according to waist circumference. In our study, the correlations of lipid, waist circumference, BMI were unexpected: positive relationship between HDL $(\mathrm{R}=0.69)$ and BMI $(\mathrm{R}=0.58)$ and negative correlation between TC and WC $(\mathrm{R}=-0.36)$ were found. Perhaps this is due to the development of adaptation processes to the increase of BMI and waist circumference. According to the German investigation of MS, $50 \%$ and $53 \%$ of the COPD patients I and II stages, and $37 \%$ and $44 \%$ of the COPD patients III and IV stages have MS. According to Spanish study results obesity was noted in $25 \%$ of COPD patients and violations of lipid metabolism were founded in $35 \%$. Among MS criteria, a lower frequency of central obesity and dyslipidemia was noted in patients with severe and extremely severe COPD: obesity was noted in $18 \%$ of the total number of COPD patients, in $25 \%$ of COPD patients with moderate severity of disease, and only in $6 \%$ of COPD patients in severe stage of COPD [31]. The bronchial obstruction, dyspnea, acrocyanosis is more expressed in COPD patients with MS.

Among other things, the difficulty of the problem is nowadays that development of polypathy (comorbidity) is typical for patients with chronic multifactorial diseases. $80 \%$ of elderly patients have 3 or more diseases, which are described as «involutional» [3]. According to the definition of entropy and synthropy [32,
2] life is an orderly and regular behavior of substance that based not only on the tendency of the transition from order to disorder, chaos, and death, but also to the constant maintenance of order and synthropy. Schrödinger [32] noted the amazing ability of the organism to concentrate on itself the «flow of order» avoiding the transition to atomic chaos associated with chromosomes. The organism produces entropy approaching death. This process is hampered by the metabolism that releases life from entropy and supports it through organization and ordering [33-34].

Nowadays, the concept of synthropy is widely used in medicine in the investigation of combined pathology, along with such related concepts as comorbidity, multimorbidity, and polypathy. This term means «mutual propensity, attraction of two diseases» as opposed to dystrophy - mutual repulsion. Despite this, there is [35-38] no clear understanding of synthropy, comorbidity, polypathy, polymorbidity. G. D. Fadeenko [39] considers the role of melatonin and nitric oxide metabolites in the pathogenesis of gastroesophageal disease associated with COPD, and concludes that combined pathology is synonymous for synthropy. It seems relevant to use the term «polypathy» in general pathology, the term "comorbidity» in clinical practice and the allocation of «synthropy» as a genetically conditioned combination of several diseases. The terms of «multimorbidity», «polymerbidity» from the standpoint of genetics and epigenetics in the future also need to be clarified.

The chronic systemic inflammation, wherein an important role belongs to lipids, is a morphological basis of polypathy in COPD. Since there are several studies that confirm the presence of common gene alleles for COPD and CAD. The opinion that COPD and CAD are synthropy diseases could be accepted.

The diagnosis of a genetic disease caused by a group of synthropic genes and its characteristic clinical phenotypes (syndromes) by way of a syndrome of progressive ireversible bronchial obstruction, a syndrome of myocardial ischemia, $\mathrm{AH}$ syndrome, a syndrome of disturbed metabolism (carbohydrate, lipid, etc.) might be expected under the conditions of further genetic identification.

The analysis of the data shows the increasing correlations between different 
indices of homeostasis with the progression of COPD in case of comorbidity. This indicates increasing of synthropy, attempts of homeostasis regulation, and search of adaptation ways to existence in conditions of severe illness.

The paradigm of reductionism was replaced by a network approach to studying the general laws and principles of human diseases. However, doctors often use polypragmazia treatment that is based on the reductionist approach [40].

The search for drugs, that are able to influence simultaneously all the links of the disturbed homeostasis, are currently underway based on the network model of the disease, the synthropy, the holistic approach to the problems of the disease [41-46]. It is proposed to use pleiotropic cholesterol-independent properties of statins as drugs such a group [41-46]. The basis of their effects is a decrease in the synthesis of intermediate cholesterol metabolism products, in particular, geranyl-geranyl pyrophosphate (GGPP) and farnesyl pyrophosphate (FPP). The anti-inflammatory effect of statins, their ability to change the properties of phagocytes, and subpopulations of T-lymphocytes were widely discussed. Cellular adhesion molecules have a moderate immunosuppressive effect. The anti-inflammatory effect of statins is accompanied with an increase in the content of antiatherogenic subfractions of LP, the cholesterol of pro-atherogenic subfractions decreases. There is evidence that statins reduce mortality from pulmonary insufficiency: a multivariate analysis of study results of statins effect in 7,700 COPD patients shows that the overall risk of death is reduced by $21 \%$ and the risk of death from a lung dysfunction violation by $45 \%$. The American College of Chest Physicians does not recommend statins for prevention of COPD exacerbations. The prescription of statins for comorbidity of COPD is recognized as a matter of debate. According to the data [43, 46], exacerbations are less frequent and mortality decreases when statins are included in the complex therapy of COPD patients.

It is possible that further research of the problem of comorbidity and synthropy in COPD will open new paths to diagnosis, treatment and prevention this serious disease.

\section{CONCLUSIONS}

1. Increase of serum triglyceride level has been found among COPD and in combination with coronary artery disease and arterial hypertension. The other parameters of the lipid spectrum are within normal ranges.

2 Significant correlations between the content of C-reactive protein and lipid spectrum parameters indicate the involvement of lipids in systemic inflammation in COPD.

3. Correlations between the lipid spectrum and total IgE in the serum, which probably shows the role of immediate type hypersensitivity in the development of comorbidity in COPD and atherosclerosis, were found.

4. Correlations between lipids, glycated hemoglobin, body mass index, and waist circumference can be signs of metabolic syndrome in COPD.

5. Cluster analysis of the homeostasis indices confirms the presence of similarity (affinity) between the parameters of the lipid spectrum, systemic inflammation, immediate type hypersensitivity, lung function in COPD patients.

6. A large number of differently directed correlation links between different indices of homeostasis in case of COPD that increases with progression of the disease, comorbidity with coronary artery disease, and may be a consequence of the processes of synthropy, adaptation, disadaptation of the organism under conditions of hypoxia. The study of the comorbidity problem, synthropy in COPD can open new approaches to diagnosis, treatment, prevention in the context of the concept of «integrative lung disease».

\section{REFERENCES}

1. Puzyrev V.P. Genetic Bases of Human Comorbidity. Genetika - Genetic 2015; 4: 491-495 (in Russ).

2. Vyatkin V.B. About application of the term «syntropy» in scientific research. Referativnyi zhurnal Abstract journal 2016; 3: 81-84 (in Russ).

3. Shirinskiy V.S., Shirinskiy I.V. Comorbid diseases are animportant problem of the clinical medicine. Sibirskyi medicinskyi zhurnal - Siberian medical journal 2014; 29(1): 7-12 (in Russ). 
4. Viliyasov V. B., Solovyeva N. V., Kremenitskaya S. A., Kuvshinova Y. V. Genetic syntropy or comorbidity? Clinical pathogenic analysis of the results of the patient study with monosomy $18 \mathrm{p}$. The modern problem of the science and education. Elektronnyi naychnyi zhurnal - Electronic scientific journal 2017; 4: UPL; https: www.sciense-education.ru/ruarticle/view? id=26660 (in Russ).

5. Kutsenko M. A., Chuchalin A. G. Paradigm of the comorbidity: the COPD and IHD synthropy. Russkyimedicinskyizhurnal - Russian medical journal 2014; 22 (5): 389-392 (in Russ).

6. Marx P., Antal P., Bolgar B., Bagdy G., Deakin B., Juhazz G. Comorbidities in the diseasome are more apparent than real: what Bayesian filtering reveals about the comorbidities of depression. PLoS Comput Biol. 2017; 13 (6): e1005487.

7. Vanflettern L. E., Spruit M. F., Groenen M. Clusters of comorbidities based on validation objective measurements and systemic inflammation in patients with chronic obstructive pulmonary disease. Am. J.Respir. Crit. Care Med. 2013; 187: 728-735.

8. Barabasi A. L. Network Medicine - from Obesity to the «Diseasome». N. Engl. J. Med. 2007; 357: 404407.

9. Kalmikov O. O. Mechanisms of realisation of cardiorespiratory disturbanses in occupational diseases of bronchopulmonary system with accompanying coronary artery disease: diagnostic and prophylactic aspects. Dissertation synopsis for the degree of $\mathrm{PhD}$, speciality 14.01.02 «Internal diseases», Kharkiv 2016; 40 p. (in Ukr).

10. Goh KI, Choi IG. Exploring the human diseasome: the human disease network. Briefings in Functional Genomics 2012; 11 (issue 6): 533-542.

11. COPD and Comorbidity. Ed. by Rabe KF, Wedzicha JA, Wouters EFM. European Respiratory Monograf 59, 2013; p.225.

12. Marshall VJ. Clinical biochemistry: translation from English. Edited by PhD Novikov NI - Moskov-StPetersburg; 1999: 245-261 (in Russ).

13. Knyshova V. V, Gvozdenko T. A, Antonyuk M. V., Novgorodtseva T. P. Dyslipidemia phenotypes among patients with chronic disease of bronchopulmonary system. Bulletin phisiologii i patologii dikhaniya Bulletin of physiology and breath pathology 2014; 51: 20-27 (in Russ).

14. Khristich T. N., Shestakova E. G., Teleki Ya. M., Gontsayruk D. A., Kushnir L. D. Comorbidity of the chronic obstructive pulmonary disease and coronary heart disease: peculiarities of pathogenic and management of patients (review of literature and own data). Ukrainskyi terapevticheskyi zhurnal Ukrainian therapiutic journal 2013; 2: 101-108 (in Russ).

15. Slepchenko N., Mostovoy Y., Sidorov A. Is high level of IgE an additional problem in smoking patients with severe and very severe chronic obstructive pulmonare disease. Europ.Respir. Journ 2012; 40 (issue supple 56): 34-41.

16. Renkema T., Kerstjens H., Schouten J., Vonk J., Koster G., Postma D. The importance of serum IgE for level and longitudinal change in airways hyperresponsiveness in chronic obstructive pulmonare diseases. Clin. Exper. Allergy 1998; 28: 1210-1219.

17. Kukshekbaeva A. S., Nasonov E. L., Masab V.P. IgE in patients with ischemic heart disease. Klinicheskaya medicina - Clinical medicine 1990; 2: 36-38 (in Russ).

18. Korkmaz V. E., Oto A., Saraclar G., Oram E., Oram A., Ugurlu S.. Karamehmetoglu A., Karamehmetoglu E. Levels IgE in the serum of patients with coronary arterial disiese. Inf. J. Cardiol. 1991; 31: 199-204.

19. Wang J. Cheng X., Xiang MX. IgE stimulates human and mouse arterial cell apoptosis and cytokine expression and promotes atherosclerosis in Apoe mice. J. Clin. Inves. 2011; 121: 3564-3577.

20. Samaha H.MS. Total serum IgE in COPD patients. Egyptian Journ. of Chest Diseases and Tuberculosis 2015; 64 (Iss.3): 573-577.

21. Bot L., Shi G.P., Covanen P. Mast cells as effectors in atherosclerosis. Atheroscler. Thromb.Vasc. Biol. 2015; 35(2): 265-271.

22. Rana J., Mittelman M., Sheikh J., Hu F. COPD, astma and risk of type 2 diabetes in women. Diab etes care 2014; 27: 2478-2484.

23. Mannino D.M., Thorn D., Swensen A., Houlquin F. Global burden of COPD: risk factors, prevalence, and future trends. Lancet 2007; 370: P. 765-773.

24. Titova E. A., Algasin A. I., Kornilova T. A. Features of the course of chronic pulmonary obstructive disease in patients with diabetes mellitus. Pulmonologiya - Pulmonology 2008; 5: 60-65 (in Russ)

25. Poulain M., Doucet M., Drapeua V. Metabolic and inflammatory profile in obese patients with chronic obstructive pulmonary diseases. Chron. Respir. Dis. 2008; 5: 35-41.

26. Ryazanov A. S., Kireev S. A., Eremenko N. N. Features chronic obstructive pulmonary disease clinical course in case of metabolic syndrome: the role of systemic inflammation. Ozhirenie i metabolism Obesity and metabolism 2010; 2: 49-51 (in Russ). 
27. Lin W. Y., Yao C. A., Wang H. C. Impaired lung function is associated with obesity and metabolic syndrome in adults. Obesity (Silver Spring) 2006; 14: 1654-1661.

28. Marquis K., Maltais F., Duquay V. The metabolic syndrome in patient with chronic obstructive pulmonary disease. J. Cardiopulm. Rheabil. 2005; 25: 226-232.

29. Park S. K., Larson J. L. Metabolic syndrome and associated factors in people with Chronic Obstructive Pulmonary Disease. Western Journal of Nursing Research. 2014; 36(5): 620-642.

30. Eisner MD, Blanc PD, Sidney S. Body composition and functional limitation in chronic obstructive pulmonaire disease. Respir. Res. 2000; 7: 1-10.

31. Steuten L.M., Creutzberg E.C., Vrijoef H.J., Wonters F.F. COPD as a multicomponent disease: Inventory of dyspnoea, underweight, obesity and fat free mass depletion in primary care. Prim. Care Respir. J. 2006; 15: 84-91.

32. Shredinger E. What is life from the physics perspectives? Translation from English by Malinovskyi A. A., Moscow, RIMIS 2009; 176 (in Russ).

33. Malinetskii G. G. Theory of self-organization. On the cusp of IV paradigm. Komputerniye issledovaniya $i$ modelirovanie - Computer research and modeling 2013; 3: 315-366 (in Russ).

34. Chernavskyi D. S. Synergetics and information (dynamic information theory). $2^{\text {nd }}$ edition, UPSS 2017; 304 (in Russ).

35. von Seht L. Weiteres uber Syntropie kindlicher Krankheitszustande. Zeitschrift fur Kinderheilkunde 1922; 31(issue 5): 208-213.

36. van Eeden S. Leipsi S. J. The relationship between lung inflammation and cardiovascular disiese. Am.J. Respir. Crit.CareMed. 2012; 186 (1): 11-16.

37. Sin D. D, Man S. F. Chronic obstructive pulmonary disease as a risk factor for cardiovascular morbidity and mortality. Proc. Am. Thorac. Soc. 2005; 2 (1): 8-11.

38. van den Akken M., Buntix T., Roos S., Knottnerus J. A. Comorbidity or multimorbidity: what is a name? A review of literature. Eur. J. Gen. Pract.1996; 2(2): 65-70.

39. Fadieienko G. D., Kamenir V. M. Relationship of melatonin metabolites and nitric oxide in pathogenesis of gastroesophageal reflux disease in combination with chronic obstructive pulmonary disease. Ukrainskyi terapevticheskyi zhurnal - Ukrainian therapiutic journal 2009; 4: 78-87 (in Russ).

40. Wong C. Y., Chandry S. I., Desai M. M. Trends in comorbidity, disability, and polypharmacy in heart failure. Am. J. Med. 2011; 124: 136-143.

41. Shirinskiy V. S., Shirinskiy I. V. Hub therapy as a new opportunity for treatment of comorbid diseases. Sibirskyi medicinskyi zhurnal - Siberian medical journal 2014; 29(4): 13-21 (in Russ).

42. Gerasimova EB, Bazdyrev ED, Smakotina SA, Hryachkova ON, Soldatova NV. Efficiency of hypolipidemic therapy at patients with chronic obstructive pulmonary disease. Medicina i obrasovanie $\mathrm{V}$ Sibiri - Medicine and education in Sibiria 2014; 2: http://ngmu.ru/cozo/mos/article/text_full.php?id=1304 (in Russ).

43. Lahousse L, Loth D, Joos G. Statins, systemic inflammation and risk of death in chronic obstructive pulmonary disease: the Rotterdame study. Pulm. Pharmacol. Ther. 2013; 26: 212-217.

44. Liao H. K., Laufs U. Pleotropic effects of statin. Ann.Rev. Pharmacol.Toxic. 2005; 45: 89-118.

45. Tandon V., Bano G., Khagjuria V. Pleotropic effects of statins. Indian J. Pharmacol. 2005; 2 (37): 77-85.

46. Yong R. P., Hopkins R., Eaton T. E. Pharmacological actions of statins: potential utility in COPD. Eur. Respir. Rev. 2009; 18: 1-11. 